\title{
«La crisis de los titiriteros»: censura e metaficção no teatro espanhol contemporâneo
}

\author{
CLAUDIO CASTRO FILHO
}

En febrero de 2016, durante los carnavales de Madrid, la obra La bruja y don Cristóbal, de la compañía granadina Títeres desde Abajo, tuvo su función interrumpida por las policías local y nacional tras la denuncia por los espectadores de que el espectáculo enaltecía el terrorismo al echar mano de una pancarta con vivas a Al Qaeda y ETA. El incidente, tratado como tema de seguridad del Estado, resultó en la detención de los artistas y conformó, en las páginas de periódicos como El País o $A B C$, un debate público que en pocas ocasiones suele incluir el teatro entre sus protagonistas. El presente artículo, partiendo de la comparación entre los reportajes vehiculados por los dos principales periódicos españoles durante los cinco días en que los titiriteros estuvieron en la cárcel, propone reflexionar sobre las estrategias discursivas de los textos periodísticos analizados, para observar algunos de los dispositivos de metaficción empleados en dicho debate público. Por último, el artículo propone reflexionar sobre algunos de los temas que motivaron el incidente en torno a la obra teatral: el lugar social del teatro de títeres, muchas veces involucrado con lo subversivo, y la construcción histórica de tabúes con respecto a los conceptos de crisis e identidad nacional.

METAFICCION / CENSURA / TEATRO DE TÍTERES / DISCURSO PERIODÍSTICO / IMAGINARIO SOCIAL

\author{
La historia es como cosa sagrada, porque ha de ser \\ verdadera, y donde está la verdad, está Dios, en cuanto \\ a verdad; pero, no obstante esto, hay algunos que así \\ componen y arrojan libros de sí como si fuesen buñuelos. \\ CERvantes, Don Quijote de La Mancha, Segunda Parte
}

Seria no mínimo surpreendente, para não dizer insólito, que um espetáculo teatral - mais, um espetáculo de teatro de bonifrates - merecesse, num período de tempo de tão-só cinco dias, mais de uma dezena de reportagens num mesmo jornal de grande circulação. La bruja y don Cristóbal, criação da companhia granadina Títeres desde Abajo, mereceu-o: entre a data da reposição da obra em Madrid, a 5 de fevereiro de 2016, e os cinco 
dias a seguir, as edições digitais dos dois jornais de informação mais lidos em Espanha, $A B C$ e El País, somaram cerca de trinta matérias a respeito daquela função, que repetia a estreia absoluta da obra em Granada, realizada, na semana anterior, na Biblioteca Social Libre Albedrío.

A razão do destaque dado ao espetáculo andaluz na comunicação social espanhola não se deveria, no entanto, a qualquer interesse estético suscitado pela obra, pelo menos não estritamente. La bruja $y$ don Cristóbal, no contexto mediático que aqui referimos, produz em Madrid um escândalo de dimensões tão ostensivas que nem mesmo os espetáculos mais demolidores ou anárquicos de Angélica Liddell ou Fernando Arrabal sonhariam alcançar. Passados poucos minutos desde o início da função vespertina no Parque Isabel II, no bairro de Tetuán, o espetáculo de bonecos do grupo granadino é interrompido pela polícia local (Unidade do Distrito de Tetuán), a cuja intervenção se somou a da polícia nacional (Brigada Provincial de Segurança Cidadã e Informação, dedicada às questões antiterroristas). O motivo da dupla intervenção: a denúncia, por parte dos espectadores, de que o espetáculo incitava à violência e ao discurso de ódio, sobretudo por supostamente elogiar o terrorismo da ETA.

E pouco mais se pode dizer sobre «a verdade dos factos». Consagrados, por tradição, como veículos de informação ideologicamente opostos, $A B C$ e El País acentuaram diferenças de abordagem no que diz respeito ao episódio da intervenção policial e, na sequência, judicial em que estiveram envolvidos os artistas da Títeres desde Abajo, sobretudo no que concerne aos dados objetivos do acontecimento. Segundo o El País, a companhia iria receber mil euros por duas funções do espetáculo: ao fim e ao cabo não recebeu, já que o delito que levou à prisão dos dois integrantes do grupo representou a conseguinte quebra do contrato (Barroso, 2016a). Para o $A B C$, o grupo não só recebeu pelo espetáculo interrompido, como recebeu um montante, mais de 23 mil euros (Anon., 2016a), extraordinariamente superior à fasquia mileurista mencionada pelo El País.

A hiperbólica discrepância entre os dois diários dá-nos, portanto, o objeto de análise do presente artigo, que pretende desenvolver, nas linhas a seguir, uma reflexão comparativa sobre a cobertura jornalística dos dois veículos em questão, no sentido de perceber alguns dos mecanismos retóricos empregados pelos textos jornalísticos na construção das suas identidades discursivas. A ostensividade mediática do «caso» (segundo o El País) ou «crise» (segundo o $A B C$ ) dos marionetistas - narrativa que terá chegado a termo, talvez, no último dia 28 de junho, com 
o arquivamento do processo pela Audiência Nacional espanhola - torna hercúlea a tarefa de uma análise global do conjunto de reportagens e artigos de opinião que, desde o início, o episódio espoletou.

Nosso enfoque recairá, assim, sobre os textos divulgados pelos dois jornais nas suas edições digitais durante o período mais crítico dos acontecimentos, situado entre os dias 6 , quando se noticia a detenção de Raúl García e Alfonso Lázaro, e 10 de fevereiro, quando se divulga a liberação dos dois.

Embora uma primeira comparação entre as ênfases e estilos de abordagem dos dois jornais revele, como acabámos de referir, uma importante discrepância de conteúdos, é interessante perceber que essa mesma discrepância é o que confere um cariz marcadamente fictício à cobertura jornalística realizada durante os cinco dias em que os marionetistas estiveram encarcerados. A falta de consenso no que respeita aos dados mais objetivos dos acontecimentos, como no caso da já supracitada remuneração do grupo teatral, afasta-nos portanto de qualquer tentação de reconstituição dos factos: interessa, aqui, perceber os mecanismos de ficção postos em cena pela comunicação social para, depois, aferir em que medida o espetáculo dos Títeres desde Abajo sustenta, esteticamente, o protagonismo a ele atribuído na esfera de um debate público onde parecem colidir, por um lado, as responsabilidades jurídicas da criação teatral e, por outro, os limites da liberdade de expressão.

Ao que parece, o primeiro ponto a considerar-se, no que diz respeito à matéria-prima das narrativas conseguidas pelo $A B C$ e El País durante a semana que aqui analisamos, é a suspensão da «ilusão» que caracteriza tanto o drama, género literário, como o dramático, tradicionalmente entendido enquanto condição de possibilidade de instauração do teatral, também no que ao espetáculo respeita. Segundo Carlos Reis (1997: 274-5), «objecto de atenção de incontáveis reflexões acerca do drama e dos géneros dramáticos, a ilusão dramática conexiona-se com questões tão diversas como a catarse e a teoria da imitação, a verosimilhança e a função ideológico-social do teatro».

Ora bem, o episódio objeto da presente análise nasce justamente de uma suspensão ou quiçá ruptura com o código ficcional da ilusão dramática, já que o público teria acionado as forças policiais madrilenas no momento em que uma das personagens da sátira guinholesca ergue um cartaz onde se lia o lema (ou palavra de ordem) «Gora ALKAETA» (em basco, «Viva ALKA-ETA»). O neologismo ALKA-ETA é lido pelo público como uma fusão entre Alcaida e ETA, bandas terroristas 
irremediavelmente ligadas a alguns dos episódios mais traumáticos da recente história espanhola, talvez por isso tornadas temas tabu, blindados à ilusão teatral. O ponto de vista da personagem de ficção é tomado, por automática metonímia, como o ponto de vista ou tese sociológica defendida pelo conjunto da obra, daí a necessidade de intervenção da força. Retenhamos, além disso, que se trata de uma personagem encarnada por um boneco, e não por um ator, o que (é de supor-se) acentuaria os códigos de artificialidade que instauram o teatral.

A suspensão ficcional que parece motivar a censura ao espetáculo contrastará, pois, com uma espécie de acento ficcional empregado pelos dois jornais na cobertura do escândalo. No caso do El País, como veremos a seguir, a estratégia de ficcionalização recairá sobre uma espécie de hiperficcionalidade atribuída à notícia, já que o jornal se centrará, nos dias que seguem à prisão dos marionetistas, em noticiar as reverberações do caso um pouco por todo o país, ressaltando certas aporias jurídicas desencadeadas pelo cariz inesperado do acontecimento: a censura teatral é, assim, lida como facto insólito no contexto de um país europeu e democrático em pleno século xxi. No caso do $A B C$, por sua vez, a componente ficcional do espetáculo de teatro em questão é diminuta se comparada àquilo que a mesma obra significa enquanto acontecimento oficial, na medida em que se trata de uma contratação pública: a encomenda, pela Autarquia de Madrid, de um serviço de entretenimento oferecido, além disso, no espaço público da cidade. Não há, portanto, distanciamento estético a considerar-se, mas há, sim, toda uma estratégia de linguagem levada a cabo pela redação do $A B C$ no sentido de ficcionalizar o quid pro quo político desencadeado ao redor dos factos. Vejamos, então, como os dois veículos desenvolvem, cada qual à sua maneira, as ditas estratégias discursivas.

A considerar a velocidade com que se passa a noticiar o caso desde a prisão dos dois criadores teatrais no dia 6 de fevereiro, não seria exagero dizer que o El País tarda em manifestar uma posição editorial da sua cobertura jornalística, algo que ocorrerá a partir do final do dia 8, com a crónica do jornalista Rubén Amón, à qual se seguiu, no dia 9, a de Marc Carrillo, catedrático de Direito Constitucional da Universidade Pompeu Fabra. $\mathrm{O}$ artigo de Amón começa por denunciar «la desproporción con que han sido tratados los sátiros del escándalo municipal», acentuando o cariz ficcional que contextualiza o emprego do cartaz pró-terrorista: «la pancarta era un recurso narrativo que incriminaba a un poli corrupto». Na ação dramática de La bruja y don Cristóbal, portanto, o Policial (vilão) tenta 
incriminar a Bruxa (heroína) ao esconder entre os pertences dela o tal cartaz com a mensagem de apologia ao terror e também uma almôndega-bomba. A despeito de um certo esforço de compreensão sobre a natureza artificial do drama de bonecos - aspecto reiteradamente desconsiderado, num primeiro momento, pelos dispositivos legais postos em ação desde a interrupção do espetáculo (as polícias municipal e nacional, a procuradoria e o juiz do caso), Amón escusa-se de uma defesa aberta da liberdade de expressão dos marionetistas. Passados já dois dias de um irrefreável debate público, qualquer posição firme, seja ela a defesa ou a acusação, está visivelmente conotada como uma posição partidária. Assumir a defesa dos marionetistas já seria, portanto, colaborar com a «estrategia victimista de Podemos». Segundo Amón, os podemistas «han convertido a los titiriteros en mártires de la libertad de expresión al arbitrio de una justicia ancien régime» (Amón, 2016).

No artigo do dia seguinte, Carrillo repete o argumento de Amón no que se refere à condição ficcional da obra, mas consegue demarcar-se das suas implicações com o debate partidário então a decorrer, quiçá porque o seu lugar como académico da área jurídica confira suficiente autoridade ao seu discurso, amparado pelo conhecimento profissional da Lei. No entanto, se é verdade que o catedrático lança mão de antecedentes jurídicos que possam justificar uma defesa dos marionetistas, também é verdade que o fundamento principal da sua argumentação a favor da liberdade de expressão dos granadinos é de foro prioritariamente estético. Carrillo começa por rememorar uma sentença ditada em 2013 pelo Tribunal de Estrasburgo para um caso similar ao episódio de Madrid. Surge, na sentença europeia, uma definição jurídica do conceito de sátira: «forma de expresión artística y de comentario social, que a partir de la exageración y la deformación de la realidad, tiene por objeto provocar y excitar las conciencias». Carrillo, a seguir, põe uma nova camada ficcional sobre o jogo discursivo, e é aqui que excederá, de certo modo, o debate jurídico. Além de não se poder ignorar o caráter naturalmente satírico da obra teatral em causa, há que considerar que a função cénica decorria no contexto da programação carnavalesca de Madrid. O Carnaval, como festa pagã marcada pela irreverência e pela inversão da norma, acrescenta uma dupla camada ficcional a La bruja y don Cristóbal, que passa a estar duas vezes autorizada (por ser teatro e por ser Carnaval) ao discurso dito anárquico: 
[...] en ningún caso se puede pasar por alto que la comedia de títeres no se producía en abstrato sino en el marco de las fiestas de carnaval. Un contexto en el que el exceso, la exageración verbal y estética, forman parte del ADN de esta manifestación lúdica de la libertad de los humanos.

(Carrillo, 2016)

A desconsideração da dupla camada ficcional que caracteriza o espetáculo (a sua natureza teatral e satírica) e o contexto (as festas de Carnaval) parece criar uma aporia no debate público que o El País somente a partir do artigo de opinião de Marc Carrillo passará a evidenciar. O mais explícito exemplo será a reportagem de Cristina Huete publicada no dia 10 e que relata a intervenção policial, em Ourense, na Galiza, contra um jovem fantasiado de marionetista que portava um cartaz com a mesma mensagem que protagonizou os episódios de Madrid poucos dias antes. O novo episódio, esteticamente marcado pela multiplicidade de camadas satíricas que espoleta (estamos diante da representação de uma representação), cria, segundo a repórter, um verdadeiro paradoxo da realidade, onde verdade e ficção se tornam categorias absolutamente instáveis e provisórias:

Cuando en pleno bullicio de la fiesta del carnaval el joven vio que se acercaban a él media docena de agentes para interpelarlo pensó que se trataba de una parodia propia del festejo, pero inmediatamente uno de los agentes lo trasladó hasta el furgón policial en donde fue identificado. (Huerte, 2016)

O relato tem como foco a suspensão dos códigos de verosimilhança que caracterizam o festejo: é próprio do Carnaval inverter a ordem do quotidiano e dos papéis sociais, daí que o jovem interpretasse os agentes policiais como paródia da própria polícia, e não como o que de facto eram. No estudo de Marlene Fortuna (2005: 83) sobre a perenidade dos ritos dionisíacos nas culturas contemporâneas, lemos que «as inversões carnavalizantes de Dioniso são permeadas de todas as características típicas da carnavalização: o grosseiro, o cômico, os valores contrários, o riso, a sátira». Na estratégia editorial do El País, a notícia chegada desde Ourense funciona como uma espécie de espelho dos factos que geraram, naquela semana, toda a polémica em redor dos marionetistas. Em Ourense, os policiais reais foram confundidos com tipos satíricos, ao passo que, no espetáculo dos granadinos, o policial de trapo que ostentou 
a mensagem pró-terrorismo foi tomado ao pé da letra, isto é, como consciência real, em posse de um discurso político por cuja responsabilidade jurídica o autor deve responder criminalmente. De certo modo, a notícia de Ourense servirá como reforço à argumentação de Carrillo dois dias antes e auxiliará o jornal numa defesa pública da liberdade de expressão dos marionetistas apartada do debate partidário, isto é, daquilo que Amón chamou de estratégia podemista de converter os criadores da Títeres desde Abajo em «mártires de la libertad de expresión.»

A acareação do episódio de Ourense com o seu referente, o episódio de Madrid, caracteriza-se, sob diversos aspectos, como relato metaficcional, uma vez que é próprio da metaficção desbordar os limites entre realidade e ficcionalidade, submetendo tanto a obra como o real à desconfiança cética. Na medida em que a obra dos Títeres desde Abajo teve o seu estatuto ficcional forçosamente suspenso pela Lei, também a Lei, representada pelos policiais de Ourense, é submetida ao crivo da dúvida: são policiais ou são sátiros? A estratégia do El País é, portanto, um dispositivo literário, que faz recordar o episódio evocado por Stendhal em Racine et Shakespeare:

O ano passado (Agosto de 1822), o soldado que estava de serviço no interior do teatro de Baltimore, ao ver Otelo que, no quinto acto da tragédia com esse nome, ia matar Desdémona, exclamou: «Nunca se dirá que na minha presença um maldito negro matou uma mulher branca.» Nesse momento, o soldado dispara a espingarda e parte um braço do ator que fazia de Otelo. (apud Reis, 1997: 275)

A estratégia de metaficcionalização do episódio transplantado para as páginas jornalísticas também será utilizada pelo $A B C$, apesar de que com outros contornos. Neste caso, o jornal conservador - que repetirá, em muitas das reportagens, o adjetivo «anarquistas» sempre que alude aos dois criadores da companhia andaluza - optará pela retórica irónica, utilizando a imagem da marioneta e do universo teatral ao seu redor como metonímia para se referir às personagens «reais» que protagonizarão a crise política desencadeada desde a prisão dos integrantes da Títeres desde Abajo. Como veremos, são diversos os momentos nos quais o léxico próprio do universo dos bonifrates é empregado para caracterizar o desenlace político ou jurídico do episódio.

$\mathrm{O} A B C$ concordará com o El País no tratamento da defesa dos marionetistas como sinónimo de vinculação ao Podemos. Esta relação de 
similitude ficará clara, nos dois jornais, com a ênfase atribuída às opiniões, favoráveis à liberação de Raúl e Alfonso, emitidas nas declarações públicas de Pablo Iglesias, secretário-geral do Podemos, e Ada Colau, autarca de Barcelona e máximo expoente do braço catalão do partido. Neste contexto, no dia 7 de fevereiro, o $A B C$ destaca, em matéria não assinada (como a maioria das matérias do $A B C$ ), a resposta de Alberto Fernández Díaz, líder do Partido Popular Catalão na autarquia barcelonesa, às declarações de Colau, que, segundo Fernández Díaz, «actúa más cual títere de los antisistema que como alcaldesa» (Anon., 2016b). Reitera-se a ideia de que a defesa dos granadinos põe em causa a idoneidade institucional da justiça espanhola, caracterizando, por conseguinte, uma postura antissistema típica de uma estratégia partidária. A metáfora da autarca como marioneta cumpre a função de demonstrar um silogismo segundo o qual qualquer um que se pronuncie publicamente a favor da libertação dos marionetistas detidos está a pronunciar-se, também, a favor de uma legenda partidária.

Três dias depois, duas matérias do mesmo $A B C$ lançarão mão do vocabulário do universo dos bonifrates para comentar a saída de Raúl e Alfonso da prisão. A primeira delas é publicada passadas duas horas da liberação dos marionetistas e comenta que o grupo de cerca de vinte amigos que os acompanhavam à porta do estabelecimento prisional de Soto del Real empurraram os repórteres presentes e os acusavam de «manipulación» (Anon., 2016c). Duas horas mais tarde, sobe à plataforma digital do $A B C$ uma nova reportagem, desta vez com a assinatura da jornalista Tatiana G. Rivas, cuja primeira frase consiste em: «La gestión de la crisis de los titiriteros está tensando los hilos que unen al Gobierno de Ahora Madrid con sus votantes» (Rivas, 2016). O recurso à imagem de uma «tensão nos fios» concorda portanto com o léxico que o jornal já empregara desde os dias anteriores.

Numa analogia à estratégia discursiva do El País, centrada na inversão metaficcional, ao $A B C$ parece interessar uma franca politização do espetáculo celebrado no Parque Isabel II, como se por metonímia o conteúdo anárquico de La bruja y don Cristóbal representasse a própria «anarquia» com que se governa a capital espanhola. Vale a pena destacar, no entanto, que o $A B C$ divulga, com maiores detalhes que o El País, o conteúdo do recurso apresentado pela defesa dos marionetistas na tentativa de reverter o quadro de prisão preventiva. Também no que diz respeito à publicação do recurso, que consta da reportagem veiculada no dia 8 de fevereiro, o jornal utilizará o artifício discursivo da marionetização das personagens reais: 
Además, el recurso precisa que uno de los actores encarcelados padece un síndrome polimalformativo que le provoca que una parte de su cuerpo esté más desarrollada que la otra. «Derivar a una persona con una embriopatía congénita tan severa a prisión supone un riesgo excesivo e inaceptable» (Anon., 2016d)

Ou seja, há qualquer coisa de estranho no corpo do marionetista, certo hibridismo ou assimetria fisionómica, proveniente de uma síndrome, que equivale fisicamente à dissimetria do corpo artificial da marioneta. Esta ambivalência ou ambiguidade entre o extraordinário e o verosímil, que no decorrer dos dias traça um mapa narrativo de múltiplas direções ficcionais, conduz-nos à indagação sobre que mecanismos ou características do espetáculo dos Títeres desde Abajo - ou, mais, da festa em que se insere o mesmo - justificam ou fundamentam a propósito da sua cobertura mediática. Isto é, que requisitos apresenta aquele espetáculo de bonecos de trapo para espoletar o que os jornais qualificam como crise política?

Já tratámos, aqui, do caráter de exceção da festa de Carnaval, na qual se insere a função interrompida da qual nos ocupamos. Autores como Georges Minois (2003), ao indagarem sobre o sentido antropológico do riso sem entraves no contexto dos carnavais, observam o engano como traço típico das celebrações dionisíacas: «esse deus [Dioniso] é perigoso, ambíguo, ambivalente, perturbador, misterioso, inquietante» (Minois, 2003: 109). No âmbito do teatro clássico, também ele enquadrado no culto a Dioniso, o engano parece expressar-se no efeito, cómico ou catártico, da ironia, figura de linguagem à qual recorrem tanto a tragédia como a comédia: «esse mundo de cabeça para baixo não é [...] gratuito em Dioniso, tem um sentido religioso profundo, ou seja, através de tantas perversões deve-se ler, como metáfora, o triunfante esforço da humanidade para divinizar-se» (Fortuna, 2005: 83).

A despeito do enorme abismo temporal que nos separa dos antigos, interessa perceber a matriz sociológica que cimenta o recurso ao teatro no contexto da suspensão da norma evocado pelas festas do Carnaval, no sentido de especularmos a respeito de uma possível predisposição do coletivo social para que o impacto estético produzisse, em avalancha, um efeito também político. Seria exagero dizer que o espetáculo granadino desencadeou por si mesmo uma crise política em Madrid, mas antes que serviu de estopim para crispações internas num contexto de governação complexo, posto que a autarquia da capital é gerida por uma coligação 
mista entre partidos de centro-esquerda (PSOE), esquerda (IU, Podemos) e plataformas civis sem filiação partidária (das quais provém a autarca Manuela Carmena). O diálogo político no contexto de um tecido partidário plural será naturalmente marcado pela negociação entre forças que nem sempre se põem, à partida, de acordo. No contexto da polémica ou crise dos marionetistas, surge então uma brecha - isto é, um pretexto para trazer a público (ou melhor, ao público) algumas das dessintonias que atravessam as conversas internas do Palácio de Cibeles.

Mas, afinal, o que caracterizou a crise política espoletada pelo espetáculo de bonifrates? De certo modo, a mesma ambiguidade sintática que se expressou na confusão entre o real e o ficcional nos episódios carnavalescos de Madrid e Ourense. Embora, no processo que decorreu na Audiência Nacional, Raúl García e Alfonso Lázaro sejam de facto os acusados, surge na narrativa uma terceira personagem, cujo papel aparece pouco definido no guião: Celia Mayer, a responsável pela pasta da Cultura na autarquia madrilena. Mayer é réu e é, também e contraditoriamente, acusação. O ponto de vista depende, já se percebeu, do jornal em que se lê a notícia. É acusada, através de uma querela apresentada à mesma Audiência Nacional onde corre o processo contra os marionetistas, pela Associação de Vítimas do Terrorismo (AVT) de ser colaboradora num crime de enaltecimento do terrorismo. O PP (e, no rescaldo, o Ciudadanos) - que terá como porta-voz, durante a crise, a presidente da Comunidade Autónoma de Madrid, Cristina Cifuentes - exige a sua demissão. Enquanto réu, Mayer protagonizará reportagens do $\mathrm{ABC}$, como a veiculada no dia 8 de Fevereiro (Anon., 2016e). Só que há outra Mayer, a do El País, que desta vez não é réu, antes acusação. Nesta outra faceta, a conselheira de cultura (em representação da Madrid Destino, empresa pública responsável pela contratação da Títeres desde Abajo) também apresenta uma querela contra os marionetistas, não por enaltecimento do terrorismo, mas relativamente «a la posibilidad de que se cometieran actos ofensivos o lesivos para la sensibilidad del público, especialmente el infantil, durante la obra» (Barroso, 2016b).

Motiva a censura ao espetáculo dos Títeres desde Abajo o recurso de La bruja y don Cristóbal a um tema tabu, de difícil digestão no debate público, como é o caso do terrorismo da ETA. Surpreende, na cobertura jornalística, que passe praticamente despercebida menção à Alcaida que a mesma mensagem encerrava. No caso do El País, o conjunto de reportagens no mais das vezes menciona a dupla «filiação» do neologismo 
que compõe as palavras de ordem do cartaz que espoletou a polémica, «cuando una marioneta sacó una pancarta con el lema "Gora Alka-ETA", en relación al grupo terrorista islámico $\mathrm{Al}$ Qaeda y a la banda vasca» (ibidem). No entanto, na cobertura dos protestos favoráveis à libertação dos artistas (reportagem de Álvaro Sánchez publicada no dia 10), também se nota que a tónica recai sobre o tema tabu: «Entre los asistentes a la protesta en Madrid había [...] carteles con frases que incluían la palabra ETA como Gora mi tromp-eta o Gora mi servill-eta» (Sánchez, 2016). Ilustra a mesma reportagem uma fotografia da agência EFE na qual se reconhece uma manifestante cujo cartaz expressa «Gora mi chaq-eta, mi camis-eta, mis tetas». No caso do $A B C$, a ênfase no tema fraturante ocorre de forma ainda mais explícita: no dia 7 de fevereiro lemos que os marionetistas foram detidos «por ensalzar a ETA» (Anon., 2016f) no dia 8 que «mostraron carteles con vivas a ETA» (Anon., 2016g) única ocorrência, no conjunto de textos consultados, onde a palavra «cartel» (cartaz) aparece no plural.

O que se nota, então, é que o espetáculo mediático montado ao redor da censura a La bruja y don Cristóbal é qualificado como crise porque traz à baila temas que, historicamente, estão conotados com a noção de crise nacional. O Carnaval de 2016 coincide, em Espanha, com a agudização da impossibilidade de acordo entre as diversas forças políticas que, ao cabo da última legislatura do PP, integram o parlamento espanhol, com a condicionante de que nenhuma delas detém uma maioria absoluta e de que a única hipótese de governação passa a ser o acordo entre legendas raras vezes perfeitamente alinhadas. Neste contexto, no qual o estatuto jurídico das diversas nacionalidades que compõem o mapa de Espanha ocupa quase sempre a ordem do dia, os temas relacionados à ETA e aos separatismos basco ou catalão são conotados como fraturantes.

No dia 10 de fevereiro, o $A B C$ dedica toda uma reportagem às declarações do ministro do interior, Jorge Fernández Díaz, sobre a questão dos marionetistas («Fernández Díaz comparte "plenamente” la decisión del juez con los titiriteros»). Nas declarações que o $A B C$ alude e cita, o ministro afirma que «existe una "agenda oculta" en las negociaciones entre los tres partidos [PSOE, Podemos e PNV] que contempla medidas de acercamiento de presos de ETA al País Vasco» (Anon., 2016h). As declarações do ministro integram, assim, mais um indício da espécie de teoria da conspiração na qual se insere o espetáculo granadino e que tem a Autarquia de Madrid como base de operações. A conspiração denunciada pelo $A B C$ vai no sentido contrário do que expressava o El País um 
dia antes, 9 de fevereiro, na reportagem de Fran Serrato, que destaca que Manuela Carmena, a autarca de Madrid, na direção da qual começam a convergir as responsabilidades políticas pelo elogio à ETA, é «una jueza de profesión que estuvo amenazada por ETA» (Serrato, 2016). Embora se deva considerar que o tema fraturante em questão surge historicamente agravado pela experiência, coletiva e traumática, do terrorismo, a tensão entre o forjar uma identidade nacional espanhola agregadora e a expressão de identidades regionais centrífugas à realidade castelhana comparece na esfera social em diversos momentos históricos de Espanha. Não seria exagero afirmar que a ideia de crise está de certo modo imbricada com a própria ideia de modernidade e é sob tal perspectiva que o pensamento da chamada Edad de Plata espanhola, numa espécie de contrarresposta ao Desastre de 1898, se debruçará sobre o imaginário das identidades da nação. No célebre ensaio En torno al casticismo, Miguel de Unamuno denuncia o regionalismo e o cosmopolitismo como dois sintomas do problema espanhol, na medida em que o primeiro teria como porta-vozes os «más apegados a doctrinas tradicionales de vieja cepa castellana» e o segundo, por sua vez, os «otros que, dejándose penetrar de cultura extraña, apenas piensan en castellano» (1966: 783-4). Ou seja, a insistência numa unidade cultural da nação expressa-se, para o filósofo, como sintoma da crise tanto quanto a recusa de um marco identitário comum. Alguns anos depois, Ortega y Gasset responderá às elucubrações do reitor de Salamanca, mas chamará de «particularismo» o que Unamuno designou «regionalismo» e de «nacionalismo» o que antes fora «cosmopolitismo». Para Ortega, no entanto, essa dinâmica entre o regional e o nacional não constitui propriamente um sintoma ou um problema, antes representa uma dialética intrínseca à própria ideia de nação, que tem o jogo ou tensão entre o centro e as periferias como condição de possibilidade: «la energía unificadora, central, de totalización -llámese como se quiera-, necesita para no debilitarse de la fuerza contraria, de la dispersión, del impulso centrífugo perviviente en los grupos» (Ortega y Gasset, 2014: 40).

As diversas reflexões sobre identidade da nação oriundas do pensamento canónico da Edad de Plata servem-nos, portanto, como analogia à crise identitária que parece costurar o pano de fundo da polémica gerada a partir do espetáculo granadino, cuja censura está diretamente ligada ao tema fraturante do terrorismo separatista. Sobretudo no que diz respeito à ideia de fratura da nação alinhavada por Ortega no seu clássico ensaio, o conceito de nação invertebrada segue vigente em reflexões 
contemporâneas sobre a dimensão histórica da noção de crise nacional. Philippe Nourry (2015) analisa o peso da história na condição invertebrada da Espanha atual, apontando o caminho federativo como possibilidade de conciliação entre as diversas nacionalidades que integram o complexo mapa cultural espanhol. Pedro Ibarra (2016), por sua vez, observa que, no período de implementação da atual democracia espanhola, as decisões da classe política relativamente ao bem-estar social e às ilusões políticas herdadas das décadas anteriores constituíram um fenómeno que se expressou numa desestruturação social que os anos 70 não permitiam pressagiar. $\mathrm{O}$ argumento do investigador basco servirá de base para, entre outras, as teses de John Sullivan (1988) e Antoni Batista (2012).

Do ponto de vista estético, já que a pedra de toque da «crise» foi um espetáculo de teatro, é interessante perceber igualmente algumas especificidades do universo do guignol que tradicionalmente lhe conferem um cariz subversivo. A personagem de don Cristóbal que protagoniza o espetáculo dos Títeres desde Abajo em questão corresponde ao estereótipo de uma personagem fortemente vinculada à tradição popular andaluza, nomeadamente no que se refere ao género dos títeres de cachiporra, cuja génese histórica se perde nas teias da literatura oral, mas que os seus estudiosos parecem vincular, também, à figura do Polichinela da commedia dell'arte italiana.

O recurso da defesa de Raúl García e Alfonso Lázaro, ao fim e ao cabo, expressa justamente o caráter subversivo dessa figura do teatro popular e apresentava alguns antecedentes, na moderna literatura dramática espanhola, no que se refere à presença de don Cristóbal e dos seus traços de caráter derrisório ou anárquico, segundo noticia o $A B C$ no dia 8 de fevereiro (Anon., 2016i). Entre os autores mencionados, aparecem, portanto, dramaturgos canónicos, nomeadamente Jacinto Benavente e Federico García Lorca. Os nomes não são citados ao acaso: o primeiro fora de certo modo marginalizado pela intelectualidade engajada espanhola em razão da sua conivência com a ditadura de Miguel Primo de Rivera nos anos 20, colaboração a que se soma a forte aceitação da sua obra nos primeiros anos do franquismo - regime interessado em capitalizar para as suas filas intelectuais a fama daquele que recebeu o Nobel de Literatura em 1922; o segundo, muito pelo contrário, enfrentou ainda em vida episódios de censura justamente à sua obra de acento guinholesco, como foi o caso da montagem de Amor de don Perlimplín que o grupo Caracol tentou emplacar em Madrid em 1929 (cf. Plaza Chillón, 
1998: 205-16) - episódio de rechaço que parecia antecipar o seu futuro fuzilamento pela Falange franquista, em 1936. Ao fim e ao cabo, o que o argumento da defesa dos artistas andaluzes sustenta é que, independentemente da orientação ideológica do autor que manuseie o aparato farsesco das marionetas, há toda uma tradição, literária e cénica, que respalda o conteúdo dito heterodoxo do espetáculo em questão. No que a Benavente e Lorca respeita, são incontáveis os estudos sobre o processo de canonização das suas dramaturgias para bonecos, mas, entre os que se destacam nas últimas décadas, podemos referir as investigações de Mario Hernández (1992: 227-39) e Luis T. González del Valle (1992: 275-84).

$\mathrm{Na}$ medida em que o espetáculo mediático ao redor de La bruja y don Cristóbal teve pauta sobretudo nos artifícios discursivos em redor de um esmaecimento da fronteira entre o real e a ficção, é interessante observar como o universo dos bonifrates está, também ele, pautado no jogo metaficcional. E aqui valeria a pena mencionarmos uma cena de Tragicomedia de don Cristóbal y la señá Rosita, de Lorca, onde o jogo metalinguístico sobre a natureza corpórea da personagem nos dá algumas chaves de leitura da problematização estética que o universo dos bonecos desperta:

FÍGARO. ¡Esto es admirable! Ya me figuraba yo. ¡Pero qué cosa más estupenda! Don Cristobita tiene la cabeza de madera. ¡De madera de chopo! ¡Ja, ja, ja! (La Niña se acerca más.) Y mirad, mirad cuánta pintura... ¡cuánta pintura! ¡Ja, ja, ja!

CANSA-ALMAS. (Que sale.) Se va a despertar.

FÍGARO. En la frente tiene dos nudos. Por aquí, sudará la resina. ¡Ésta era la novedad! ¡La gran novedad! (García Lorca, 1997, II: 67)

A cena em que o barbeiro afinal descobre a natureza corpórea de don Cristóbal - isto é, descobre que se trata de um boneco, de um corpo artificial - coaduna-se com a particularidade do cariz vanguardista da dramaturgia lorquiana. Por um lado, o recurso metateatral, expresso na reiterada denúncia da teatralidade e na explicitação dos artifícios cénicos, alinha a sua dramaturgia de bonifrates aos experimentos de vanguarda de começos do século Xx. Por outro, esse mesmo cariz vanguardista configura-se com cor local, fincado na tradição popular e no retorno aos clássicos dos Siglos de Oro; Lorca repete, aqui, o recurso à ruptura das ilusões que o próprio Cervantes pôs em ação no capítulo Xxvi da Segunda Parte do Quixote, no célebre episódio do «Retablo de Maese Pedro», com cuja 
versão operista o próprio poeta granadino colaborou, nos anos 20, junto com Manuel de Falla e Hermenegildo Lanz. No episódio em questão, dom Quixote não reconhece a natureza artificial dos bonecos que se apresentam no retábulo e toma a história encenada por realidade nua e crua, daí que «con acelerada y nunca vista fúria», comece a «llover cuchilladas sobre la titerera morisma, derribando a unos, descabezando a otros, estropeando a éste, destrozando a aquél...», a despeito da advertência de Maese Pedro de que «estos que derriba, destroza y mata no son verdaderos moros, sino unas figuras de pasta» (Cervantes, 2004: 755). Trata-se, justamente, do episódio quixotesco que serviu de título ao já mencionado artigo de opinião de Rubén Amón no El País, «No dejar títere con cabeza».

Parece ser este, portanto, o imaginário que se reapresenta no episódio da criminalização dos bonecos no espetáculo de Madrid. Não por acaso, Fernando Matos Oliveira (2010: 118) lê o célebre ensaio de Kleist Sobre $o$ Teatro de Marionetas como um texto elucidativo da crise modernista, naquilo que revela sobre a potência da marioneta enquanto «busca dramática de um sentido para a experiência» ou como tentativa agónica de «corrigir a divergência entre o sujeito e o mundo». Para Arnaud Rykner (2004: 319-323), a marioneta forma parte do conjunto de «forças rebeldes» contra a centralidade da palavra no teatro ocidental, na medida em que potencializa o discurso corpóreo, a expressão do indizível e do que não se pode traduzir em palavras.

Nota-se, na mobilização espoletada pelo espetáculo dos Títeres desde Abajo, que somos incapazes de perdoar às marionetas aquilo que perdoamos aos homens. A despeito da inegável prerrogativa autoral e experimental assumida pelo teatro de formas animadas no contexto contemporâneo, o que o episódio vivido pelos Títeres desde Abajo demonstra é que, em alguma medida, segue vigente um certo imaginário social, de raízes históricas, que vê o teatro de bonecos como algo naturalmente subversivo. Ana Vidal Egea (2010: 21), ao analisar o cariz marginal dos primeiros passos dramatúrgicos de Angélica Liddell, associa a construção discursiva da artista espanhola à sua experiência inicial com o teatro de bonecos. Daniela Rosante Gomes (2011: 23) observa que a incorporação da dramaturgia de bonecos no teatro de Lorca obedece justamente a um projeto do autor de recuperar uma cultura andaluza marginalizada. O que, do ponto de vista antropológico, é de difícil compreensão (mas que parece manifestar-se como fenómeno), é uma espécie de hiper-realidade que a extrema 
artificialidade do corpo do boneco põe em movimento: suspendem-se, como vimos, os códigos da ilusão dramática.

No caso de La bruja y don Cristóbal, a esta dimensão antropológica do teatro (nomeadamente a do teatro de bonifrates), soma-se o contexto do Carnaval, que, como festa derrisiva e esteticamente ligada à inversão da ordem, ocupa desde sempre uma geografia necessariamente política. De qualquer forma, a forte repercussão mediática da censura ao espetáculo granadino indicia o cariz excepcional dos dispositivos de cerceamento à expressão teatral no contexto europeu atual. Os avatares da censura estão aí e podem manifestar-se a diversos níveis (desde logo nas políticas públicas para a área cultural, nas condicionantes económicas que envolvem a produção/circulação de artefactos culturais, etc.). No entanto, não se torna fácil explicitá-los ou defendê-los no espaço público, daí o arquivamento do processo contra Raúl García e Alfonso Lázaro em 28 de junho de 2016.

\section{REFERÊNCIAS BIBLIOGRÁFICAS}

AMÓN, Rubén (2016), «No dejar títere con cabeza», El País, 8 de Fevereiro.

ANON. (2016a), «Fernández Díaz comparte "plenamente" la decisión del juez con los titiriteros», $A B C, 10$ de Fevereiro.

ANON. (2016b), «Ada Colau pide la libertad para los titiriteros», $A B C, 7$ de Fevereiro.

ANON. (2016c), «Colau culpa al PP “corrupto” del encarcelamiento de titiriteros», $A B C, 10$ de Fevereiro.

ANON. (2016d), «Los abogados de los titiriteros comparan su obra con Pesadilla en Elm Street», ABC, 8 de Fevereiro.

ANON. (2016e), «Cifuentes pide la dimisión de la concejala de cultura», $A B C, 8$ de Fevereiro.

ANON. (2016f), «Ada Colau pide la libertad para los titiriteros», $A B C, 7$ de Fevereiro.

ANON. (2016g), «Catalá respeta la prisión para los titiriteros», $A B C, 8$ de Fevereiro.

ANON. (2016h), «Fernández Díaz comparte "plenamente” la decisión del juez con los titiriteros», $A B C, 10$ de Fevereiro.

ANON. (2016i), «Los abogados de los titiriteros comparan su obra con Pesadilla en Elm Street», ABC, 8 de Fevereiro. BARRoso, F. Javier (2016a), «Ahora Madrid rechaza que los titiriteros hicieran apología del terrorismo», El País, 7 de Fevereiro.

-- (2016b), «Ahora Madrid rechaza que los titiriteros hicieran apología del terrorismo», El País, 8 de Fevereiro. BAT ISTA, Antoni (2012), Adiós a las armas: Una crónica del final de ETA, Londres, Penguin Random House. CARRILLO, Marc (2016), «Sátira y titiriteros», El País, 9 de Fevereiro.

CERVAntes, Miguel de (2004), Don Quijote de La Mancha, ed. e notas de Francisco Rico, Madrid, Real Academia Española / Asociación de Academias de la Lengua Española.

FORTUNA, Marlene (2005), Dioniso e a Comunicação na Hélade: O mito, o riso e a ribalta, São Paulo, Annablume. GARCÍA LORCA, Federico (1997), Obras Completas, 4 vols., ed. Miguel García-Posada, Barcelona, Galaxia Gutenberg. Gomes, Daniela Rosante (2011), Do Idílio ao Porrete: A dramaturgia para títeres de Federico García Lorca, Uberlândia, UFU. 
GONZÁLEZ DEL VALLE, Luis T. (1992), «La recepción literaria-teatral y la definición del canon: el caso de Jacinto Benavente», in DOUGHERTY, Dru e VILCHES DE FRUTOS, M. Francisca (coords.), El teatro en España entre la tradición y la vanguardia, Madrid, CSIC / Fundación Federico García Lorca / Tabacalera, pp. 275-84.

HERNÁNDEZ, Mario (1992), «Falla, Lorca y Lanz en una sesión granadina de títeres», in DOUGHERTY, Dru e VILCHES DE FRUTOS, M. Francisca (coords.), El teatro en España entre la tradición y la vanguardia, Madrid, CSIC / Fundación Federico García Lorca / Tabacalera, pp. 227-39.

Huerte, Cristina (2016), «La policía identifica a un joven disfrazado de titiritero en Ourense», El País, 10 de Fevereiro.

IBARRA, Pedro (2016), Memoria del antifranquismo en el País Vasco, Arre (Navarra), Pamiela.

MINOIS, Georges (2003), História do Riso e do Escárnio, trad. Maria Helena O. Ortiz Assumpção, São Paulo, UNESP. NOU RRY, Philippe (2015), Histoire de l'Espagne: Des origines à nos jours, Paris, Tallandier.

OLIVEIRA, Fernando Matos (2010), «A ensaística teatral: texto, espaço e utopia», in GoulART, Rosa Maria (coord.), Poéticas do Ensaio, Coimbra, Centro de Literatura Portuguesa / Universidade dos Açores, pp. 117-30.

ORTEG A Y GASSET, José (2014) [1914], España invertebraday otros ensayos, Madrid, Alianza.

PLAZA CHILlón, José Luis (1998), Escenografía y artes plásticas: el teatro de Federico García Lorca y su puesta en escena (1920-1935), Granada, Fundación Caja de Granada.

REIS, Carlos (1997), O Conhecimento da Literatura: Introdução aos estudos literários, 2. a ed., Coimbra, Almedina. RIVAS, Tatiana G. (2016), «Rebelión interna contra Carmena», $A B C$, 10 de Fevereiro.

RYKNER, Arnaud (2004), O Reverso do Teatro: Dramaturgia do silêncio da idade clássica a Maeterlinck, trad. Dóris Graça Dias, Lisboa, Fundação Calouste Gulbenkian.

SÁNCHEZ, Álvaro (2016), «Centenares de manifestantes piden retirar los cargos contra los titiriteros», El País, 10 de Fevereiro.

SERRATO, Fran (2016), «Carmena investigará el caso de los títeres...», El País, 9 de Fevereiro.

SUllivAN, John (1988), ETA and Basque Nationalism: The Fight for Euskadi, Londres, Routledge.

UnAmuno, Miguel de (1966), Obras completas, vol. I, ed. Manuel García Blanco, Madrid, Escelicer.

VIDAl EGEA, Ana (2010), El teatro de Angélica Liddell (1988-2009), Madrid, UNED.

\section{CLAUDIO CASTRO FILHO}

Claudio Castro Filho é doutor em Literatura Comparada pela Universidade do Estado do Rio de Janeiro (2012), onde também se licenciou em História da Arte (2005) e foi professor de Estética e Teoria da Arte (2007-2012). Mestre pelo Departamento de Artes Cênicas da Universidade Estadual de Campinas, no campo do teatro, trabalha nas áreas da encenação, dramaturgia e tradução. Assinou diversos títulos, entre os quais o mais recente Eu Mesma Matei Meu Filho: Poéticas do trágico em Eurípides, Goethe e García Lorca (Imprensa da Universidade de Coimbra, 2016). Investigador integrado no Centro de Estudos Clássicos e Humanísticos da Universidade de Coimbra, enquadrado no grupo de investigação Semântica e Pragmática da Arte. É desde 2013 bolseiro de pós-doutoramento pela Fundação para a Ciência e Tecnologia e neste contexto leva a cabo uma investigação, repartida entre as universidades de Coimbra e Granada, sobre a fase vanguardista de Federico García Lorca. 